\title{
Analisis Penggunaan Media Pembelajaran Untuk Meningkatkan Motivasi Peserta Didik Terhadap Pembelajaran Fisika Kelas XI MIPA 1 SMA Titian Teras Muaro Jambi
}

\author{
Novita Sari ${ }^{1}$, Krisna Suryanti ${ }^{2}$, Santy Meilisa Manurung ${ }^{3}$, Sintia $^{4}$ \\ 1,2,3,4) Program Studi Pendidikan Fisika, Universitas Jambi \\ Email:novita.u7@gmail.com¹; suryanti.krisna@yahoo.com²; santymanurung05@gmail.com³; \\ chyn.sintia@gmail.com ${ }^{4}$
}

Received May 31, 2017; Revised August 21, 2017; Accepted September 29, 2017

\begin{abstract}
Abstrak
Penelitian ini bertujuan untuk mengetahui pengaruh penggunaan media pembelajaran terhadap motivasi pembelajaran fisika kelas XI MIPA 1 SMA Titian Teras. Jenis penelitian yang digunakan adalah penelitian analisis deskriptif. Hasil penelitian menunjukkan bahwa rata-rata tingkat motivasi belajar termasuk dalam kriteria sedang. Penelitian tentang motivasi belajar siswa kelas XI MIPA 1 SMA TitianTeras MuaroJambi, menunjukkan bahwa rata-rata tingkat motivasi belajar termasuk dalam kriteria sedang untuk siswa kelas XI MIPA 1 SMA TitianTeras MuaroJambi .Banyak faktor yang mempengaruhi kontribusi terhadap pencapaian nilai rata-rata siswa, salah satunya motivasi belajar. Motivasi belajar sangat penting dalam proses pembelajaran karena proses belajar membutuhkan interaksi dan partisipasi aktif dari peserta didik untuk berhasil.
\end{abstract}

Kata kunci: media, motivasi

\begin{abstract}
This study aims to determine the effect of the use of learning media on the learning motivation of physics class XI MIPA 1 SMA Titian Teras. The type of research used is descriptive analysis research. The results showed that the average level of learning motivation included in the criteria are. Research on the motivation of students learning class XI MIPA 1 SMA Titian Teras Muaro Jambi, showed that the average level of learning motivation included in the criteria are for students of class XI MIPA I SMA Titian TerasMuaro Jambi. Many factors that influence the contribution to the achievement of the average value of students, one of them motivation to learn. Motivation learning is very important in the learning process because the learning process requires the active interaction and participation of learners to succeed.
\end{abstract}

Keywords: media, motivation

DOI : 10.25273/jpfk.v3i2.1297

\section{PENDAHULUAN}

Pelajaran Fisika bagi sebagian siswa merupakan pelajaran yang kurang disukai. Padahal, kontribusi ilmu Fisika dalam pengembangan ilmu pengetahuan dan teknologi sangat besar, sehingga penting untuk dipelajari. Hasil wawancara dengan beberapa peserta didik Sekolah Menengah Atas Titian Teras Muaro Jambi mengungkapkan bahwa mereka merasa kesulitan dalam belajar Fisika karena materinya banyak yang abstrak, banyaknya persamaan matematika yang harus dipelajari, merasa bosan dan jenuh, kegiatan belajar yang tidak menyenangkan, dan monoton.
Pembelajaran yang bersifat monoton akan sulit diterima oleh peserta didik. Apalagi pada usianya, mereka cenderung menyukai pembelajaran yang bervariasi. Pada kondisi seperti ini, diharapkan dapat menciptakan suasana pembelajaran yang menarik, sehingga motivasi peserta didik untuk belajar Fisika semakin meningkat. Salah satu cara untuk membangkitkan motivasi belajar peserta didik adalah dengan menggunakan media. Media dalam pembelajaran dapat membangkitkan keinginan dan minat yang baru, membangkitkan motivasi dan merangsang belajar, serta membawa pengaruh psikologis terhadap siswa. Media pembelajaran dapat menyampaikan pesan dari sumber secara terencana, sehingga 
terbentuk lingkungan yang kondusif dimana penerimanya dapat melakukan proses belajar secara efisien dan efektif. Media yang digunakan dalam pembelajaran berfungsi sebagai jembatan atau media transformasi pelajaran terhadap tujuan yang ingin dicapai. Lebih jauh lagi Sutarman menyatakan bahwa belajar dengan bantuan media komputer dan teknologi informasi dapat mempermudah siswa dalam menerima pelajaran. Temuan lapangan yang ada di SMA TT Muaro Jambi sebanyak 13 peserta didik masih mengalami kesulitan belajar khususnya pada materi analisis gerak melingkar dikarenakan salah satu penyebabnya adalah pada materi ini terdapat banyak rumus dan pengaplikasiannya.

Menurut Suparman dalam Sutikno (2013:106) media didefinisikan sebagai alat yang digunakan untuk menyalurkan pesan atau informasi dari pengirim ke penerima pesan. Media dalam aktivitas pembelajaran dapat didefinisikan sebagai sesuatu yang dapat membawa informasi dan pengetahuan dalam interaksi yang berlangsung antara pendidik dengan siswa. Media dalam pengertian lain diartikan sebagai perantara seperti yang diungkapkan oleh Yudhi Munandi (2013: 8) bahwa media adalah segala sesuatu yang dapat menyampaikan dan menyalurkan pesan dari sumber secara terencana sehingga tercipta lingkungan belajar yang kondusif di mana penerimanya dapat melakukan proses belajar secara efisien dan efektif. Dari kedua pengertian di atas dapat dipahami bahwa media pembelajaran adalah alat bantu apa saja yang dapat dijadikan sebagai penyalur pesan untuk memperoleh hasil pembelajaran yang maksimal.

Tujuan yang ingin dicapai dari penelitian ini adalah untuk mengetahui pengaruh penggunaan media pembelajaran terhadap motivasi pembelajaran fisika kelas XI MIPA 1 SMA Titian Teras.

\section{METODE}

Metode yang digunakan dalam penelitian ini adalah analisis deskriptif. Penelitian analisis deskriptif yaitu jenis penelitian survei yang bertujuan untuk meningkatkan motivasi peserta didik terhadap pembelajaran fisika kelas XI MIPA 1 SMA Titian Teras Muaro Jambi”.

Analisis deskriptif persentase digunakan untuk menggambarkan fenomena penelitian yaitu penggunaan media pembelajaran terhadap motivasi pembelajaran fisika kelas XI MIPA 1 SMA Titian Teras Muaro Jambi.

\section{HASIL DAN PEMBAHASAN}

Berdasarkan hasil analisis, diperoleh tingkat motivasi belajar siswa kelas XI MIPA 1 di SMA Titian Teras Muaro Jambi yang disajikan pada grafik di bawah ini.

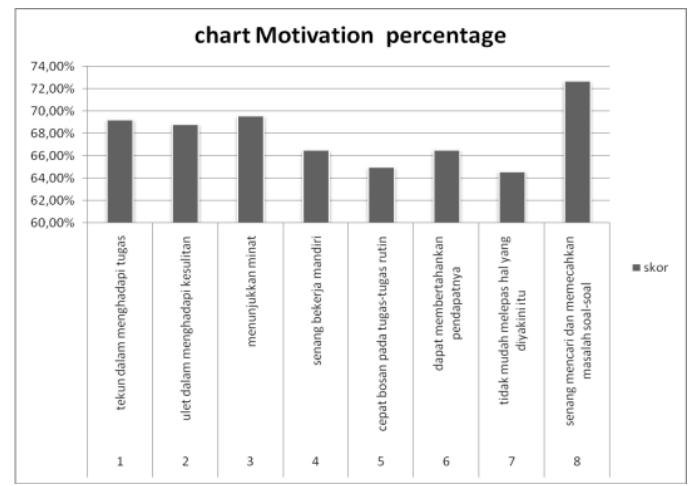

Gambar 1. Tingkat motivasi peserta didik dalam belajar

Pada penelitian ini menggunakan angket motivasi serta wawancara beberapa siswa kelas XI MIPA 1 SMA Titian Teras Muaro Jambi. Dari diagram diatas terlihat bahwa kemandirian belajar memiliki presentasi yang rendah, yang ditunjukkan dalam indicator 4,5 , dan 7. Dari skala $100 \%$ untuk motivasi belajar, untuk kemandirian hanya mencapai $36 \%$. Nilai dari persentasi tersebut menunjukkan bahwa adanya pengaruh motivasi terhadap kemandirian belajar siswa.

Berdasarkan diagram diketahui bahwa rata-rata tingkat motivasi belajar termasuk dalam kriteria sedang. Penelitian tentang motivasi belajar siswa kelas XI MIPA 1 SMA 
Titian Teras Muaro Jambi, menunjukkan bahwa rata-rata tingkat motivasi belajar termasuk dalam kriteria sedang untuk siswa kelas XI MIPA 1 SMA Titian Teras Muaro Jambi. Banyak faktor yang mempengaruhi kontribusi terhadap pencapaian nilai rata-rata siswa, salah satunya motivasi belajar. Motivasi belajar sangat penting dalam proses pembelajaran karena proses belajar membutuhkan interaksi dan partisipasi aktif dari peserta didik untuk berhasil.

Tingkat motivasi belajar siswa kelas XI MIPA 1 SMA Titian Teras Muaro Jambi, termasuk dalam criteria sedang menunjukkan bahwa dorongan dalam diri mereka untuk berprestasi cukup baik. Sebagian kecil dari angket dan wawanccara menunjukkan tingkat kemandirian dengan sangat tinggi.

Berdasarkan hasil wawancara dengan beberapa siswa kelas XI MIPA 1 SMA Titian Teras Muaro Jambi, diperoleh bahwa siswa merasa jenuh dalam mempelajari materi-materi fisika, khususnya materi analisis vector dan gerak melingkar. Rasa jenuh siswa muncul karena tidak ada motivasi yang dilakukan oleh guru pada saat proses pembelajaran. Fakta ditemukan di lapangan bahwa masih ada guru yang kurang memanfaatkan penggunaan media dalam pembelajaran khususnya dalam mata pelajaran fisika. Pernyataan tersebut dibuktikan dengan media yang digunakan di sekolah tersebut terdiri atas papan tulis, LKS dan buku paket. Untuk mengatasi permasalahn tersebut, penulis menganalisis bahwa dengan penggunaan media pembelajaran dapat meningkatkan motivasi belajar siswa khususnya pada mata pelajaran fisika.

\section{KESIMPULAN}

Berdasarkan hasil pembahasan di atas dapat ditarik simpulan yaitu berdasarkan diagram diketahui bahwa rata-rata tingkat motivasi belajar termasuk dalam kriteria sedang. Motivasi belajar sangat penting dalam proses pembelajaran karena proses belajar membutuhkan interaksi dan partisipasi aktif dari peserta didik untuk berhasil. .
Siswa merasa jenuh dalam mempelajari materi-materi fisika, khususnya materi analisis vector dan gerak melingkar. Rasa jenuh siswa muncul karena tidak ada motivasi yang dilakukan oleh guru pada saat proses pembelajaran. Fakta ditemukan di lapangan bahwa masih ada guru yang kurang memanfaatkan penggunaan media dalam pembelajaran khususnya dalam mata pelajaran fisika. Untuk mengatasi permasalahn tersebut, penulis menganalisis bahwa dengan penggunaan media pembelajaran dapat meningkatkan motivasi belajar siswa khususnya pada mata pelajaran fisika.

\section{UCAPAN TERIMAKASIH}

Terimakasih kepada Dosen Pembimbing Ahmad Syarkowi, S.Pd.,M.Pd yang telah membimbing dan mendanai penelitian ini,sehingga penelitian ini dapat terselesaikan.

\section{DAFTAR PUSTAKA}

Arsyad, A. 2011. Media Pembelajaran. PT Raja Grafindo Persada: Jakarta.

Asyhar, R. 2011. Kreaatif Mengembangkan Media Pembelajaran. Gaung Persada (GP) Press: Jakarta.

Sudjana, N. 2009. Dasar-dasar Proses Belajar Mengajar. Sinar Baru Algesindo:Bandung.

Sudjana, N., Rivai, A. 2011. Media Pembelajaran. Sinar Baru Algesindo:Bandung.

Sugiyono. 2008. Metode Penelitianuantitatif, Kualitatif dan R \&D. Alfabeta:Bandung.

Purwanto, Ngalim. 2012. Prinsip-prinsip dan Teknik Evaluasi Pengajaran. Rosdakarya: Bandung.

Rohmani, dkk. Pengembangan Media Pembelajaran Fisika Berbasis Multimedia Interaktif Terintegrasi Dengan Lks Pokok Bahasan Hukum Newton Tentang Gerak Kelas X SMA/MA ISSN: 2252-7893, Vol 4, No. I, 2015 (hal 152-162) http://jurnal.fkip.uns.ac.id/index.php/sains 